This is the accepted manuscript of the following article: Rafael, R. B. A., Fernández-Marcos, M. L., Cocco, S., Ruello, M. L., Weindorf, D. C., Cardelli, V., and Corti, G. (2018). Assessment of Potential Nutrient Release from Phosphate Rock and Dolostone for Application in Acid Soils. Pedosphere 28, 44-58. doi: 10.1016/S10020160(17)60437-5.

(C) 2018 Soil Science Society of China Published by Elsevier B.V. and Science Press. This manuscript version is made available under the CC-BY-NC-ND 4.0 license

\title{
Assessment of potential nutrient release from phosphate rock and dolostone for application in acid soils
}

\author{
Rogério Borguete Alves Rafael ${ }^{\mathrm{ab}}$; Maria Luisa Fernandez-Marcos ${ }^{\mathrm{c}}$; Stefania Cocco $^{\mathrm{b}}$; Maria Letizia Ruello ${ }^{\mathrm{d}}$; \\ David C. Weindorf ; Valeria Cardelli ${ }^{\mathrm{b}}$, Giuseppe Corti ${ }^{\mathrm{b}}$
}

aDepartment of Rural Engineering, University Eduardo Mondlane, 257, Maputo, Mozambique

bDepartment of Agriculture, Food and Environmental Sciences, Università Politecnica delle Marche, 60131 Ancona, Italy

${ }^{c}$ Department of Soil Science and Agricultural Chemistry, Universidad de Santiago de Compostela, 27002 Lugo, Spain

dDepartment of Materials, Environmental Sciences and Urban Planning, Università Politecnica delle Marche, 60131 Ancona, Italy

${ }^{\mathrm{e} D e p a r t m e n t ~ o f ~ P l a n t ~ a n d ~ S o i l ~ S c i e n c e, ~ T e x a s ~ T e c h ~ U n i v e r s i t y, ~ L u b b o c k, ~ T X, ~ U S A ~}$

Corresponding author: rogerborguete@gmail.com; rogerio.rafael@uem.mz

Other authors: mluisa.fernandez@usc.es; s.cocco@univpm.it; m.1.ruello@univpm.it; david.weindorf@ttu.edu; v.cardelli@pm.univpm.it; g.corti@univpm.it

\begin{abstract}
The aim of this study was to evaluate the feasibility of using phosphate rock and dolostone as fertilizer and amendment, respectively, for application in tropical acid soils. The dissolution of different particle-size fractions by water and citric acid was studied. Laboratory column experiments were run following a completely randomized design, by using $0.063-0.25,0.25-0.5$, and $0.5-2 \mathrm{~mm}$ particle-size fractions of both rocks. Each rock particle-size was subjected to exhaustive dissolution with distilled water, citric acid solution at $\mathrm{pH} 4$, and citric acid solution at $\mathrm{pH}$, with the following extraction times: 1, 3, 5, 7, 12, 24, 72, 144, 240, and $360 \mathrm{~h}$. The dissolution of both rocks depended on particle-size, leaching solution and extraction time. The dissolution rate of rock-forming minerals augmented as the specific surface area increased, corresponding to a decrease in particlesize. In all cases, the kinetics of release was characterized by two phases: 1) a first stage of rapid release that lasted $24 \mathrm{~h}$, which would ensure short-term nutrient release, and 2) a second stage of slow release (after $24 \mathrm{~h}$ ), representing the long-term nutrient release efficiency. Both rocks are suitable as slow release fertilizers in strongly acid soils and would ensure the replenishment of $\mathrm{P}, \mathrm{Ca}$, and $\mathrm{Mg}$. A combination of fine and medium particle-size fractions should be used to ensure high nutrient release efficiency. Much work has to be done to assess the overall impact of considerable amounts of fresh rocks in soils.
\end{abstract}

Key words: citric acid, soil fertility, rock weathering, nutrient release 


\section{Introduction}

Worldwide acid soils are mainly present into two belts: 1) humid northern temperate zones, which are mostly occupied by coniferous forest, and 2) humid tropics, which host savannah systems and tropical rainforests (FAO, 2016). Acid soils are deficient in plant nutrients such as phosphorus (P), nitrogen $(\mathrm{N})$, potassium $(\mathrm{K})$, calcium (Ca) and magnesium $(\mathrm{Mg})$, while having increased availability of phytotoxic elements like aluminium (Al) and manganese (Mn) (van Straaten, 2002, 2006; Caires et al., 2005; van Raij, 2011; FAO, 2016). These deficient elements (with exception of $\mathrm{N}$ ) are mostly derived from rocks and minerals (Chien et al., 2011).

Since soil acidification strongly reduces crop production, amelioration of acid soils is paramount for food security and agriculture sustainability. Application of fertilizers can satisfy the nutrient deficiency in acid soils (Chien et al., 2011), but the cost of fertilizers, particularly of P fertilizers, has increased substantially worldwide (van Straaten, 2002, 2006; Chien et al., 2011). Therefore, finding alternative local sources of plant nutrients which could supply $\mathrm{P}$ or other elements for sustainable crop production is a practical, low-cost, long-term strategy that addresses the need of poor farmers (Appleton, 2002; van Straaten, 2002, 2006; Zapata and Roy, 2004).

Apatites and calcareous rich rocks have been tested for their application in agricultural acid soils. For instance, it is known that the reactivity of apatites can be increased through grinding, and this increases P availability and produces similar yield responses and agronomic effects to those of triple superphosphate fertilizer (van Straaten, 2002, 2006; Szilas et al., 2008).

Thus the application of limestone, possibly with a certain amount of dolomite, can mitigate soil acidity, prevent $\mathrm{Al}$ and Mn toxicity (Álvarez et al., 2012; van Straaten, 2002, 2006, 2007), and provide Ca and Mg to the soil (Viadé et al., 2011). Consequently, food production and quality are enhanced (Maria and Yost, 2006). In addition, both apatitic and calcareous rocks may contain a wide range of minor chemical elements, some of which are beneficial for plant nutrition (IAEA, 2002; Szilas et al., 2007; van Straaten, 2006).

In Mozambique, acid soils cover $\sim 70 \%$ of the country (Gouveia and Azevedo, 1949). Here, two important rock outcrops merit consideration: a metamorphic phosphate rock and a dolostone. Mineralogically, these two rocks are extremely relevant for mitigating acidity and replenishing $\mathrm{P}, \mathrm{Ca}$, and $\mathrm{Mg}$. Their importance is even more significant considering that African Countries cannot afford to purchase expensive water soluble phosphatic fertilizers, but could exploit their own rock outcrops, with reduced and controlled environmental risks (Khasawneh and Doll, 1978; Appleton, 2002; van Straaten, 2006, 2007). 
Phosphatic rocks and dolostones vary widely in their mineralogical and physicochemical properties. Consequently, their reactivity and agronomic potential also vary (IAEA, 2002; Szilas, 2002; Szilas et al., 2007, 2008). Thus it is prudent to evaluate their fertility value in terms of nutrient release to assess their possible use for crop production while minimizing fertilizer requirements (van Straaten, 2002; Zapata and Roy, 2004).

The dissolution rate of rocks tested for their possible use in agriculture mainly depends on their mineralogical composition as well as on the solubilizing acid and $\mathrm{pH}$ of the extracting solution (Goyne et al., 2006; Calvaruso et al., 2013). Low molecular weight organic acids (LMWOAs) are preferred to others, citric and oxalic acids being the most used (IAEA, 2002). In fact, citric acid originates in soil from the secretions of plant roots and soil microorganisms like fungi, lichens, and prokaryotes (Olsson and Wallander, 1998; Goyne et al., 2006; Joergensen and Wichern, 2008; Klugh-Stewart and Cumming, 2009; Goyne et al., 2010), and can simulate the weathering occurring in the rhizosphere (Turpault et al., 2009; Calvaruso et al., 2013).

For instance, when apatites are exposed to citrate and oxalate ligands, the release of $\mathrm{P}$ and $\mathrm{Ca}$ is the highest (Goyne et al., 2006, 2010). Instead, the dissolution of calcareous minerals such as calcite $\left(\mathrm{CaCO}_{3}\right)$ and dolomite $\left[\mathrm{CaMg}\left(\mathrm{CO}_{3}\right)_{2}\right]$ depends on solution $\mathrm{pH}, \mathrm{pCO}_{2}$, temperature, and mineral properties such as crystallinity (Yasuda et al., 2013) as well as specific surface area (van Straaten, 2002, 2006, 2007). Dolomite dissolution rates are usually lower than those of calcite (Liu et al., 2005; Dewaide et al., 2014).

This study aims to investigate the feasibility of using a phosphate rock and a dolostone from local sources in Mozambique, ground to different grain sizes (0.063-0.25, 0.25-0.5, and 0.5-2 mm), as sources of $\mathrm{P}, \mathrm{Ca}$, and $\mathrm{Mg}$ or acid-neutralising agents. We assessed their effectiveness by testing their solubility in water and different concentrations of citric acid solutions in open-system columns under controlled conditions. We hypothesize that both rocks will provide substantive nutrient release in support of agronomic production and that finer particle size will facilitate enhanced solubility.

\section{Materials and Methods}

\subsection{Sample preparation}

Both studied rocks are from Mozambique. The phosphate rock was collected from the Nampula Province deposit in the Evate district, while dolostone was collected from the Mount Muambe deposit located in the Tete Province. Blocks of rocks were fragmented by using a grinding press; then the rock fragments were ground using an agate mortar. For both rocks, three size-fractions were obtained by dry sieving: $0.063-0.25,0.25-0.5$ and $0.5-2$ mm. 


\subsection{General characterization}

The mineralogical composition was determined on powdered rocks by x-ray diffraction with a Philips PW 1830 diffractometer, using the Fe-filtered $\mathrm{Co} \mathrm{K} \alpha 1$ radiation $(35 \mathrm{kV}$ and $25 \mathrm{~mA})$; the step size was $0.02^{\circ} 2 \theta$ and the scanning speed was one second per step. A semi-quantitative estimation was obtained after the identification of the minerals on the basis of their characteristic peaks as reported by Dixon and Schulze (2002), and MINCRYST database (http://database.iem.ac.ru/mincryst, accessed on $22^{\text {th }}$ June 2016).

The elemental analysis of both rocks was obtained using DP-6000 Delta Premium portable X-ray fluorescence (PXRF) spectrometer (Olympus, Waltham, MA, USA) according to Weindorf and Chakraborty (2016). The instrument features a Rh X-ray tube operated at $15-40 \mathrm{kV}$ with quantification via ultra-high resolution (165 eV) silicon drift detector. The analysis was firstly conducted in "Soil Mode" (three beams of $30 \mathrm{~s}$ each), and secondly in "Geochem Mode" (two beams of $30 \mathrm{~s}$ each). Therefore, the contents of $\mathrm{Al}, \mathrm{Si}, \mathrm{P}, \mathrm{Mg}, \mathrm{Ca}$, and $\mathrm{S}$ were validated using "Geochem Mode" readings, and the remaining elements were validated using "Soil Mode" (Weindorf and Chakraborty, 2016).

Total carbon concentration in dolostone was determined using CHNS-O analyser (EA1110, Carlo Erba Instruments, Milan, Italy). The fractions of phosphate rock were analysed for water soluble P, P extractable with neutral ammonium citrate (NAC-P), P extractable with $2 \%$ citric acid solution (citric-P), and P extractable with $2 \%$ formic acids solution (formic-P) as per Rajan et al. (1992). For each size- fraction of both rocks, $10 \mathrm{~g}$ of sample was added to $25 \mathrm{~mL}$ of distilled water, and the abrasion $\mathrm{pH}$ was measured after 6 min of solid - liquid contact (Romero et al., 1987). To measure the $\mathrm{pH}$ at $1.5 \mathrm{~h}$, the suspension was stirred for $1 \mathrm{~h}$ on an oscillating table and left to rest for $30 \mathrm{~min}$ before repeating the $\mathrm{pH}$ measurement; in a similar way, $\mathrm{pH}$ was measured at $24 \mathrm{~h}$ (Pansu and Gautheyrou, 2006).

\subsection{Leaching experiment}

To assess the long-term dissolution (reactivity) of the different size-fractions of both rocks, two sets of column experiments were conducted using a completely randomized design. Samples of the three particle-size fractions $(0.063-0.25,0.25-0.5$ and $0.5-2 \mathrm{~mm})$ of both rocks were treated for 15 days with different leaching solutions (distilled water, citric acid solution at $\mathrm{pH} 4$ and citric acid solution at $\mathrm{pH} 2$ ); leachates were retrieved at the following extraction times: 1, 3, 5, 7, 12, 24, 72, 144, 240, and $360 \mathrm{~h}$. Similarly, percolations without rock sample were conducted as controls. The experimental design consisted of three replicates for each fraction and leaching solutions. 
The experiments were conducted in an isolated room at a temperature of $25 \pm 1^{\circ} \mathrm{C}$. The leaching solutions were prepared $24 \mathrm{~h}$ prior to use by dissolving monohydrate citric acid crystals (AR manufactured by Carlo Erba Reagents $)$ in distilled water. The citric acid solution at $\mathrm{pH} 4\left(\approx 10^{-4} \mathrm{M}\right)$ was considered representative of the soil solution conditions of acid soils from tropical environments, while the citric acid solution at $\mathrm{pH} 2\left(\approx 10^{-1} \mathrm{M}\right)$ was taken as an example of extreme acidity conditions that only rarely can occur in soil, even in the rhizosphere.

Each column (diameter x length of $30 \mathrm{x} 400 \mathrm{~mm}$ ) of $200 \mathrm{~mL}$ capacity was fitted with $0.3 \mathrm{~g}$ of fiberglass at the bottom to prevent rock fragments loss. Thus, $1.000 \mathrm{~g}$ of each rock size-fraction was put into the column, and 100 $\mathrm{mL}$ of leaching solution were added (solid:liquid ratio of 1:100, w:v). At each extraction time, the liquid was allowed to percolate at a constant rate $\left(100 \mathrm{~mL} \mathrm{~h}^{-1}\right)$. Thus, $100 \mathrm{~mL}$ of fresh leaching solution was added to each column.

The elements measured in the leachate of both rocks were $\mathrm{Ca}, \mathrm{Mg}, \mathrm{K}, \mathrm{Na}, \mathrm{Ba}, \mathrm{Al}, \mathrm{Fe}, \mathrm{Mn}, \mathrm{Zn}, \mathrm{Cd}, \mathrm{Ni}, \mathrm{and} \mathrm{Pb}$; only in those from phosphate rock fractions was $\mathrm{P}$ also determined. The analyses of leachates were carried out the same day they were collected. The cations were measured by an inductively coupled plasma optical emission spectrometer (Perkin Elmer Optima 8300) as described by Boss and Fredeen (1997), while a simple colorimetric method based on ascorbic acid reduction of the ammonium phosphomolybdate complex (Kuo, 1996) was used to measure $\mathrm{P}$ in the leachates.

\subsection{Kinetic analysis}

The Langmuir (1997) equation below was used to determine the release rate using the data obtained by the leaching experiment, assuming that the dissolution of minerals in phosphate rock and dolostone were controlled by surface reaction:

$$
d C_{(t)} / d t=k ; \text { Integrated rate law: } C=C_{o}+k t,
$$

where $C_{(t)}\left(\mathrm{mol} \mathrm{L}^{-1}\right)$ is the concentration of released species in the bulk solution at the time $t ; C\left(\mathrm{~mol} \mathrm{~L}^{-1}\right)$ is the concentration of released species in the leachate after the release; $C_{o}\left(\mathrm{~mol} \mathrm{~L}^{-1}\right)$ is the initial concentration of the species in bulk solution before the release starts; $k\left(\mathrm{~mol} \mathrm{~L}^{-1} \mathrm{~s}^{-1}\right)$ is the rate constant.

\subsection{Statistical analysis}

R version 3.1.2 (2014-10-31) was used for statistical analysis. Single extraction data were analysed for analysis of variance (ANOVA) after a boxcox transformation (Meloun et al., 2005) of the data to perform parametric tests (Shapiro-Wilk normality test and Bartlett test of homogeneity of variances). A multiple comparison Tukey test 
(at 5\% significance) was used to compare the means. Similarly, data obtained from the leaching experiments were analysed using parametric tests, but they revealed a non-normal distribution and heteroscedasticity. Therefore, summary statistics (mean, variance, standard error and deviation) were used whenever possible.

\section{Results and discussion}

\subsection{Mineralogical and chemical composition of the two rocks}

X-ray diffraction analysis showed that the phosphate rock was mainly made of fluoroapatite, while the dolostone was made of dolomite (Figs. 1 and 2, respectively). Both rocks contained traces of phyllosilicates. The major constituent elements of the phosphate rock were $\mathrm{Ca}$ and $\mathrm{P}$, followed by $\mathrm{Si}, \mathrm{Al}, \mathrm{Fe}, \mathrm{K}, \mathrm{Sr}$, and $\mathrm{Ba}$; all the other elements were present in concentrations close to or $<1000 \mathrm{mg} \mathrm{kg}^{-1}$ (Table I).

The rock $\mathrm{P}$ content was $\sim 24 \%$, equivalent to $55 \%$ of $\mathrm{P}_{2} \mathrm{O}_{5}$, which satisfies the European legislation in terms of total $\mathrm{P}$ content to be used for direct application to the soil, as it exceeds the threshold value of $25 \%$ of $\mathrm{P}_{2} \mathrm{O}_{5}$ (European Commission, 2000). The concentrations of trace elements were similar to those commonly reported for phosphate rocks (Adriano, 2013). The concentrations of As and Hg were moderately high, but they should not be problematic for the application of phosphate rock to soils at moderate rates.

The major elements in the dolostone were $\mathrm{Ca}, \mathrm{Mg}$, and $\mathrm{C}$, followed by $\mathrm{Si}, \mathrm{P}, \mathrm{Al}, \mathrm{Fe}, \mathrm{K}, \mathrm{Mn}, \mathrm{Ba}, \mathrm{S}, \mathrm{Sr}$, and $\mathrm{Ti}$, with the other elements present in amounts $<40 \mathrm{mg} \mathrm{kg}^{-1}$ (Table I). The richness in $\mathrm{Ca}, \mathrm{Mg}$, and $\mathrm{C}$ was $~ 29.4$, 18.2, and $8.2 \%$, respectively, equivalent to $\sim 41,30$, and $41 \%$ of the respective oxides. The Ca: $\mathrm{Mg}$ molar ratio of 1:1 confirmed the mineralogical observation indicating that the main rock forming mineral was dolomite (AlAwadi et al., 2009). This dolostone can be considered completely safe given its low concentration of potentially hazardous trace elements.

\subsection{Phosphate rock}

\subsubsection{General properties}

For the phosphate rock, the abrasion $\mathrm{pH}$ decreased significantly $(P<0.05)$ with contact time for all fractions, ranging from 9.36 for the finest fraction at $6 \mathrm{~min}$ of solid-liquid contact, to 7.81 for the coarsest fraction after 24 h (Table II). As expected, the finest fraction presented higher $\mathrm{pH}$ values $(P<0.05)$ compared with the other fractions. This was ascribed to the higher specific surface area of this fraction. Newly formed mineral surfaces like those obtained by grinding are able to release alkaline and alkaline-earth elements and adsorb $\mathrm{H}^{+}$, so to induce an abrasion $\mathrm{pH}$ that lasts until other factors perturb the suspension (Grant, 1969; Romero et al., 1987). 
The temporal decrease of abrasion $\mathrm{pH}$ was ascribed to the dissolution of atmospheric $\mathrm{CO}_{2}(\mathrm{Grant}, 1969)$ and possibly to surface passivation (Cuniglio et al., 2009).

Single extractions of P by water, NAC, $2 \%$ citric acid solution and $2 \%$ formic acid solution showed that the $2 \%$ formic acid solution was able to extract the highest $(P<0.001)$ amount of $\mathrm{P}$ (Table III). The increase of extractable $\mathrm{P}$ with the grinding for all the extractants except water indicates the highest reactivity of the finest fraction of this rock (Rajan et al., 1992). Therefore, taking $2 \%$ formic acid solution as the best predictor of agronomic effectiveness of phosphate rock (Rajan et al., 1992), the finest size fraction features high potential ( $P$ $<0.001$ ) for a direct application in strongly acid soils (Ghani et al., 1994; Rajan et al., 1996; Zapata and Roy, 2004).

\subsubsection{Long-term release in column experiments}

(i) Cumulative releasing pattern of $\mathrm{P}, \mathrm{Ca}$, and $\mathrm{Mg}$

The cumulative release of $\mathrm{P}, \mathrm{Ca}$, and $\mathrm{Mg}$ in water and in citric acid solutions at $\mathrm{pH} 4$ and $\mathrm{pH} 2$ from different particle sizes of phosphate rock was calculated for the different extraction times. Other elements such as $\mathrm{K}$, Na, $\mathrm{Ba}, \mathrm{Al}, \mathrm{Fe}, \mathrm{Mn}, \mathrm{Zn}, \mathrm{Cd}, \mathrm{Ni}$, and $\mathrm{Pb}$ were leached in concentrations always lower than $100 \mathrm{mmol} \mathrm{kg}^{-1}$. The cumulative release of $\mathrm{P}, \mathrm{Ca}$ and $\mathrm{Mg}$ showed an increasing trend for all leaching solutions (Fig. 3). The rate of release was relatively high in the first $24 \mathrm{~h}$ of leaching and decreased thereafter, indicating that most of the extractable nutrients were released within $24 \mathrm{~h}$. For all nutrients and leaching solutions, the highest cumulative release was obtained for the finest fraction $(P<0.01)$, followed by the medium and, then, by the coarse fraction (Table IV).

The citric acid solution at pH 2 leached the highest amount of nutrients. For instance, at the end of the experiment, citric acid at pH 2 had leached from the finest fraction 27 and 86 times the amount of P obtained with the citric acid at $\mathrm{pH} 4$ and water, respectively. The amounts of $\mathrm{P}$ and $\mathrm{Ca}$ extracted by the leaching experiment were higher than those extracted by single extraction in both water and $2 \%$ citric acid solution (Table $\mathrm{V})$.

For $\mathrm{Ca}$ there was no difference between the coarse and medium size-fractions in water and citric acid solution at pH 4 and for all the extraction times. The same was true for $\mathrm{Mg}$ in the finest and medium size-fractions in the case of citric acid solution at $\mathrm{pH} 2$ during the first $72 \mathrm{~h}$ of extraction; thereafter the medium size-fraction presented a slightly higher cumulative release than the finest size fraction. 


\section{(ii) Release kinetics of $\mathrm{P}$ and $\mathrm{Ca}$}

The release kinetics was determined for both $\mathrm{P}$ and $\mathrm{Ca}$, the most important nutrients in the phosphate rock fractions. During the leaching period the release rate decreased sharply up to $24 \mathrm{~h}$, to steadily decrease until reaching values close to zero (Fig. 4). The finest fraction showed a higher release rate than the other particle-size fractions, which did not differ significantly between them, indicating that the kinetics was controlled by superficial processes (Dorozhkin, 2012).

The citric acid solution at $\mathrm{pH} 2$ showed the highest release rate, followed by citric acid solution at $\mathrm{pH} 4$. The cumulative curves showed two leaching stages: 1) a rapid release during the first $24 \mathrm{~h}$ of leaching ascribed to the presence of easily dissolvable mineral surfaces probably activated during the grinding process, which could be taken as the short-term nutrient release efficiency (Truong and Fayard, 1995; Zapata and Roy, 2004; Gholizadeh et al., 2009), and 2) a slow release after $24 \mathrm{~h}$ of leaching, where the dissolution of the bulk mineral begins representing the medium- to long-term nutrient release efficiency, which is agronomically relevant.

Most of the solid had not dissolved when the near-zero release rate was reached, and therefore only the thin layer of superficial, very fine, poorly crystalline mineral material had dissolved. The amount of $\mathrm{P}$ and $\mathrm{Ca}$ extracted in this stage was similar among the particle-size fractions $(P<0.01)$ for citric acid at $\mathrm{pH} 2$ (Table IV). The bulk mineral in the second stage was approaching the equilibrium by reaching the metastable conditions characterized by the persistence of apatite crystals with a passivated surface that reduces the reactivity of the mineral grain (Cuniglio et al., 2009). Because of this, mineral grains in contact with unsaturated solutions release lesser amounts of ions than expected from the mineral formula (Dorozhkin, 2012).

In our trial we demonstrated that the size of rock fragments and the leaching solution strength were the determinant factors for the release rates. The ideal (congruent) dissolution of fluoroapatite promoted by an organic acid is given below (adapted from Calvaruso et al., 2013):

$$
\mathrm{Ca}_{5}\left(\mathrm{PO}_{4}\right)_{3} \mathrm{~F}+6 \mathrm{AH} \leftrightarrows 5 \mathrm{Ca}^{2+}+6 \mathrm{~A}^{-}+3 \mathrm{H}_{2} \mathrm{PO}_{4}^{-}+\mathrm{F}^{-},
$$

where $\mathrm{A}^{-}$represents the organic anion

An appropriate supply of hydrogen ions $\left(\mathrm{H}^{+}\right)$and the removal of the reaction products $\left(\mathrm{Ca}^{2+}, \mathrm{H}_{2} \mathrm{PO}_{4}^{-}\right.$, and $\left.\mathrm{F}^{-}\right)$are necessary for the reaction to proceed forward (Robarge, 1999). The open system used in this study (columns) ensured the removal of the reaction products through solution percolation, while the citric acid solutions supplied $\mathrm{H}^{+}$so the release could go forward. The mechanism of dissolution of fluoroapatite by LMWOAs such as citric acid is ascribed to the supply of $\mathrm{H}^{+}$, the formation of surface complexes that weaken and break the bonds among metals and lattice oxygen (Goyne et al., 2006; Dorozhkin, 2002, 2012), and the complexation of metals (Ca, Fe, 
and $\mathrm{Al}$ ) by carboxyl ligands $(-\mathrm{COOH})$. All of these reactions entail the release of phosphorus $\left(\mathrm{H}_{2} \mathrm{PO}_{4}^{-}\right)$from the mineral (Goyne et al., 2006; Calvaruso et al., 2013).

The phosphate rock had a molar $\mathrm{Ca} / \mathrm{P}$ ratio of $\sim 1.2$ (Table I). During the leaching in water and citric acid solution at $\mathrm{pH} 4$, the molar $\mathrm{Ca} / \mathrm{P}$ ratio in solution did not reach 0.5 (Fig. 5). The much lower $\mathrm{Ca} / \mathrm{P}$ ratio in the leachates indicates the occurrence of an incongruent dissolution of fluoroapatite, since $\mathrm{P}$ was being released preferentially over $\mathrm{Ca}$. With citric acid solution at $\mathrm{pH}$, the fluoroapatite dissolution seemed to be incongruent too, even though between 24 and $72 \mathrm{~h}$ of leaching the $\mathrm{Ca} / \mathrm{P}$ ratio reached values close to the $\mathrm{Ca} / \mathrm{P}$ ratio in the initial solid phase. Yet, the finest size-fraction always displayed the highest $\mathrm{Ca} / \mathrm{P}$ ratio.

According to Harouiya et al. (2007), Dorozhkin (2002, 2012), and Crundwell (2014, 2015, 2016), Ca-apatites in acid solutions dissolve by ionic detachment of $\mathrm{Ca}$ and orthophosphate ions from the solid toward the solution. In our case, the formation of a Ca-rich layer (self - inhibition model) in both water and citric acid solution at $\mathrm{pH} 4$, probably was determinant in decreasing the dissolution rate of apatite in the second stage. Hence, the diffusion of $\mathrm{Ca}$ and orthophosphate ions occurred from the surface layer formed, so leading to incongruent dissolution (Dorozhkin, 2002, 2012).

The $\mathrm{Ca}$ rich layer was probably thicker in the second stage of leaching because of the major contact time between the unsaturated solutions and apatite crystals. Because of this, the dissolution of fluoroapatite in citric acid solution at $\mathrm{pH} 2$ proceeded at a certain rate in first $72 \mathrm{~h}$ of extraction, and decreased thereafter due the lack of removal of the Ca rich layer formed during the longer periods of solid-solution contact.

The citrate anion (and others such as oxalic, formic, etc.) have higher affinity for Ca than orthophosphate (Goyne et al., 2006; Dorozhkin, 2002, 2012) and plays a considerable role in the dissolution of phosphate rock (Wei et al., 2011; Calvaruso et al., 2013). Therefore, the citric acid used in the leaching experiments may allow predicting the dissolution of phosphate rocks in acid soils. The LMWOAs produced in the soil rhizosphere by root exudates and microbial activity (Marschner et al., 2011; Wei et al., 2011) has the capability to solubilize phosphatic particles and increase the availability of P (Kpomblekou and Tabatabai, 2003; Li et al., 2011; Cocco et al., 2013; Gómez and Carpena, 2014; De Feudis et al., 2016).

The dissolution of phosphate rock fractions can be increased by the removal of reaction products, in the plantsoil system and, even more, in the rhizosphere. Thus, Ca uptake may increase rock particle solubilization and, consequently, the availability of P for plants and microrganisms (Marschner et al., 2011; Panhwar et al., 2014). 


\subsection{Dolostone}

\subsubsection{General properties}

Similar to phosphate rock, the abrasion $\mathrm{pH}$ of dolostone decreased significantly with contact time for all the particle-size fractions ranging from 9.57 at 6 min for the medium size fraction $(0.25-0.5 \mathrm{~mm})$ to 8.25 after $24 \mathrm{~h}$ for the coarse size fraction (Table II). There were no significant differences among the size fractions during the contact time. As in the case of the phosphate rock fractions, the temporal decrease of abrasion $\mathrm{pH}$ can be attributed to the dissolution of atmospheric $\mathrm{CO}_{2}$.

\subsubsection{Long-term release in column experiments}

(i) Cumulative releasing pattern of $\mathrm{Ca}, \mathrm{Mg}$, and $\mathrm{K}$

$\mathrm{Ca}$ and $\mathrm{Mg}$ were the major elements leached during the extraction period. Other elements such as $\mathrm{Na}, \mathrm{Ba}, \mathrm{Zn}$, $\mathrm{Cd}, \mathrm{Ni}$, and $\mathrm{Pb}$ were present in concentrations close to or lower than $5 \mathrm{mmol} \mathrm{kg}^{-1}$. Despite elements such as Fe, $\mathrm{Mn}$, and $\mathrm{Al}$ being leached in concentrations lower than $30 \mathrm{mmol} \mathrm{kg}^{-1}$, namely higher than $\mathrm{K}$, here we discuss $\mathrm{K}$ together with $\mathrm{Ca}$ and $\mathrm{Mg}$ as plant macronutrients. The cumulative release of $\mathrm{Ca}, \mathrm{Mg}$, and $\mathrm{K}$ showed an increasing trend in all leaching solutions (Fig. 6). The release rate for $\mathrm{Ca}$ and $\mathrm{Mg}$ was relatively high in the first $24 \mathrm{~h}$ of leaching, and decreased thereafter. Among the particle-size fractions, the finest one showed the maximum cumulative release, followed by the medium size for $\mathrm{Ca}$ and $\mathrm{Mg}$. As expected, the citric acid solution at $\mathrm{pH} 2$ extracted substantively more nutrients than the other leaching solutions.

The cumulative pattern of $\mathrm{K}$ differed from other nutrients as the medium and coarse size-fractions showed a linear trend after $72 \mathrm{~h}$ of leaching for both citric acid solutions at $\mathrm{pH} 4$ and 2. Interestingly, water dissolved more $\mathrm{K}$ from the finest and medium fractions than citric acid at $\mathrm{pH} 4 \mathrm{did}$; even more surprisingly, citric acid at $\mathrm{pH} 4$ dissolved less $\mathrm{K}$ from the fine and medium fractions than from the coarsest fraction. We ascribed this behaviour to a mineral phase (probably calcium citrate) that precipitated upon dissolution of the fine and medium fractions and that prevents the release of $\mathrm{K}$.

\section{(ii) Release kinetics of Ca and $\mathrm{Mg}$}

The kinetics of release was assessed for both $\mathrm{Ca}$ and $\mathrm{Mg}$ as they were the most important nutrients in dolostone. During the leaching period the release rate decreased sharply up to $24 \mathrm{~h}$, followed by a steady decrease until reaching values close to zero (Fig. 7). The finest size fraction showed a slightly higher release rate than the other 
fractions. There were no significant differences between the medium and coarse sizes. The citric acid solution at pH 2 showed much higher release rates than the other leaching solutions.

Two stages of release were evident for all leaching solutions: 1) a stage of fast release in the first $24 \mathrm{~h}$, and 2) a stage of slow release after $24 \mathrm{~h}$ for all leaching solutions, probably due to the precipitation of calcium citrate during the long period of solid/liquid contact (Al-Khaldi et al., 2007). During this second stage, probably characterized by incongruent dissolution, the rates of the released $\mathrm{Ca}$ and $\mathrm{Mg}$ were higher for medium and coarse particle-size fractions $(P<0.01)$ in citric acid solution at $\mathrm{pH} 2$, while there was not much difference among particle size fractions in water and citric acid solution at pH 4 (Fig. 7, Table VI).

The release rate of $\mathrm{Ca}$ was twice that of $\mathrm{Mg}$ in both water and citric acid solution at $\mathrm{pH} 4$, and similar for both elements in citric acid solution at $\mathrm{pH} 2$ because of the considerable amounts of $\mathrm{Mg}$ dissolved by this leaching solution. In water and citric acid solution at $\mathrm{pH} 4, \mathrm{Ca}$ dissolved preferentially compared to $\mathrm{Mg}$ during most of the extraction time and the releasing was non-stoichiometric (Fig. 5). In citric acid solution at pH 2, after a short period of preferential release of $\mathrm{Ca}$, the molar $\mathrm{Ca} / \mathrm{Mg}$ ratio dropped to values close to 1 , the $\mathrm{Ca} / \mathrm{Mg}$ ratio in dissolved rock, because of the low pH (Pokrovsky et al., 2009). The ideal (congruent) dissolution of calcareous minerals due to an organic acid is given below (adapted from Pansu and Gautheyrou, 2006):

$$
\begin{gathered}
\mathrm{CaCO}_{3}+2 \mathrm{AH} \leftrightarrows \mathrm{Ca}^{2+}+2 \mathrm{~A}^{-}+\mathrm{H}_{2} \mathrm{O}+\mathrm{CO}_{2} \text { (fast reaction) } \\
\mathrm{MgCO}_{3}+2 \mathrm{AH} \leftrightarrows \mathrm{Mg}^{2+}+2 \mathrm{~A}^{-}+\mathrm{H}_{2} \mathrm{O}+\mathrm{CO}_{2} \text { (slow reaction), }
\end{gathered}
$$

where $\mathrm{A}^{-}$represents the organic anion

The dissolution rate of dolomite is generally slower than that of calcite and in acid solution is affected by the transport rate of the reactants, surface reaction, and transport rate of products away from the surface (Yasuda et al., 2013). The same as in the phosphate rock, the open system of columns used in this study ensured the removal of products and the supply of $\mathrm{H}^{+}$by citric acid solutions, so favouring the dissolution of dolostone. This explanation is in accordance with the sharp decrease of $\mathrm{Ca} / \mathrm{Mg}$ ratio in the first $24 \mathrm{~h}$ of leaching, which was due to the increase of $\mathrm{Mg}$ release.

In citric acid solution at $\mathrm{pH} 2$, the steady decrease of $\mathrm{Ca} / \mathrm{Mg}$ ratio after $24 \mathrm{~h}$ of leaching was ascribed to higher dissolution of the remaining carbonates (enriched in $\mathrm{Mg}$ ). The higher affinity of the citrate anion for Ca over $\mathrm{Mg}$ (Dorozhkin, 2002, 2012) and the leaching of the reaction products were the driving force of dolostone dissolution. The high citrate concentration in citrate solution at $\mathrm{pH} 2$ favored the complexation of $\mathrm{Mg}$, rendering the dissolution congruent in the later periods of leaching. Thus, this type of rock can be used for $\mathrm{pH}$ correction 
and $\mathrm{Ca}$ plus Mg replenishment for plant uptake, while mitigating Al toxicity (Conyers et al., 1996; Conyers, 2003; Viadé et al., 2011; Bothe, 2015; da Costa and Crusciol, 2016; Tiritan et al., 2016).

The LMWOAs such as citric acid promote dolostone dissolution by complexing both $\mathrm{Ca}$ and $\mathrm{Mg}$ from the rock surface (Manahan, 2000; Zimdahl, 2015) resulting in an increase of nutrients (Panhwar et al., 2014; da Costa and Crusciol, 2016). Based on leaching curves, the dolostone will have a much higher impact in strongly acid soils, even though the slower release rate of dolomite within the dolostone will ensure the long-term efficiency of nutrient release.

\section{Conclusions}

The leaching experiments run in an open-system (columns) under controlled conditions showed that the nutrient release from phosphate rock and dolostone fraction was mainly a function of particle-size, strength of the leaching solution, and time. Increased concentrations of citric acid solution resulted in a greater dissolution. The application of the tested rocks fractions to strongly acid soils from tropical areas is suitable as they behave like slow release fertilizers that are able to replenish the soil with $\mathrm{P}, \mathrm{Ca}$, and $\mathrm{Mg}$ with the benefit of liming.

Application of the coarse size fraction $(0.5-2 \mathrm{~mm})$ of both rocks demands less energy inputs for crushing and grinding than other sizes; however the reactivity of this size fraction is low, and its application to the soil would be much less effective than finer size-fractions. The application of both fine and medium grained materials might represent a good balancing to ensure a short and medium-term release of nutrients and alkalizing species. Managing the rhizosphere activities to promote the production of LMWOAs will be a good strategy to improve nutrient release by these rocks fractions in acid soils. Much work has to be done to transfer these lab results to the field, in particular on the overall impact of considerable amounts of fresh rocks added to tropical soils.

Acknowledgments Funds for this work were mainly obtained from "Applied Research and Multi-sectorial Program" (FIAM)" granted by Italian Cooperation and Development Agency (ICDA) to the Universidade Eduardo Mondlane, under the project contract $\mathrm{N}^{\circ}$. 5.2.1. The authors also acknowledge the Polytechnic University of Marche (Ancona, Italy) for PhD scholarship provided to the first author and research funding for this work. Any findings, conclusion and recommendation presented in this document do not necessary reflect the views of the donors. 


\section{References}

Adriano, D.C. 2013. Trace Elements in the Terrestrial Environment. Springer Science and Business Media, New York.

Al-Awadi, M., Clark, W.J., Moore, W.R., Herron, M., Zhang, T., Zhao, W., Hurley, N., Kho, D., Montaron, B., Sadooni, F. 2009. Dolomite : Perspectives on Perplexing Mineral. Oilfield Review. 21: 32-45.

Al-Khaldi, M.H., Nasr-El-Din, H.A., Mehta, S., Al-Aamri, A.D. 2007. Reaction of citric acid with calcite. Chemical Engineering Science. 62: 5880-5896.

Álvarez, E., Fernández-Sanjurjo, M.J., Nuñez, A., Seco, N., Corti, G. 2012. Aluminium fractionation and speciation in bulk and rhizosphere of grass soil amended with mussel shells or lime. Geoderma. 173: 322-329. Appleton, J.D. 2002. Local phosphate resources for sustainable development in Sub-Saharan Africa. British Geological Survey Report, CR/02/121/N. Keyworth, Nottingham, UK.

Boss, C.B., Fredeen, K.J. 1997. Concepts, instrumentation and techniques in Inductively coupled plasma optical emission spectrometry. Perkin Elemer, USA.

Bothe, H. 2015. The lime-silicate question. Soil Biology and Biochemistry. 89: 172-183.

Caires, E.F., Alleoni, L.R.F., Cambri, M.A., Barth, G. 2005. Surface application of lime for crop grain production under a no-till system. Agronomy Journal. 97: 791-798.

Calvaruso, C., Turpault, M.P., Frey-Klett, P., Uroz, S., Pierret, M.C., Tosheva, Z., Kies, A. 2013. Increase of apatite dissolution rate by Scots pine roots associated or not with Burkholderia glathei PML1(12) Rp in opensystem flow microcosms. Geochimica et Cosmochimica Acta. 106: 287-306.

Chien, S., Prochnow, L., Tu, S., Snyder, C.S. 2011. Agronomic and environmental aspects of phosphate fertilizers varying in source and solubility: an update review. Nutrient Cycling in Agroecosystems. 89: 229-255. Cocco, S., Agnelli, A., Gobran, G.R., Corti, G. 2013. Changes induced by the roots of Erica arborea L. to create a suitable environment in a soil developed from alkaline and fine-texture marine sediments. Plant Soil. 368: $297-313$.

Conyers, M.K., Scott, B.J., Fisher, R., Lill, W. 1996. Predicting the field performance of twelve commercial liming materials from southern Australia. Fertilizer Research. 44: 151-161.

Conyers, M. 2003. Amelioration of acidity with time by limestone under contrasting tillage. Soil and Tillage Research. 72: 85-94.

Crundwell, F.K. 2014. The mechanism of dissolution of minerals in acidic and alkaline solutions: Part I — A new theory of non-oxidation dissolution. Hydrometallurgy. 149: 252-264. 
Crundwell, F.K. 2015. The mechanism of dissolution of the feldspars: Part I. Dissolution at conditions far from equilibrium. Hydrometallurgy. 151: 151-162.

Crundwell, F.K. 2016. The mechanism of dissolution of minerals in acidic and alkaline solutions: Part VI a molecular viewpoint. Hydrometallurgy. 161: 34-44.

Cuniglio, R., Corti, G., Agnelli A. 2009. Rock fragments evolution and nutrient release in vineyard soils developed on a thinly layered limestone (Tuscany, Italy). Geoderma. 148: 375-383.

da Costa, C.H.M., Crusciol, C.A.C. 2016. Long-term effects of lime and phosphogypsum application on tropical no-till soybean-oat-sorghum rotation and soil chemical properties. European Journal of Agronomy. 74: 119132.

De Feudis, M., Cardelli, V., Massaccesi, L., Bol, R., Willbold, S., Cocco, S., Corti, G., Agnelli, A. 2016. Effect of beech (Fagus sylvatica L.) rhizosphere on phosphorous availability in soils at different altitudes (central Italy). Geoderma. 276: 53-63.

Dewaide, L., Baele, J.M., Collon-Drouaillet, P., Quinif, Y., Rochez, G., Vandycke, S., Hallet, V. 2014. Karstification in dolomitized Waulsortian mudmounds (Belgium). Geologica Belgica. 17: 43-51.

Dixon, J.B., Schulze, S.G. 2002. Soil Mineralogy with Environmental Applications. Soil Science Society of America Book Series. No 7. Soil Science Society of America, Inc., Madison, Wisconsin, USA.

Dorozhkin, S.V. 2012. Dissolution mechanism of calcium apatites in acids: A review of literature. World Journal of Methodology. 2: 1-17.

Dorozhkin, S.V. 2002. A review on the dissolution models of calcium apatites. Progress in Crystal Growth and Characterization of Materials. 44: 45-61.

European Commission, 2000. Official Journal of the European Communities. 269: 1-15.

FAO. 2016. Acid Soils. Available online at http://www.fao.org/soils-portal/soil-management/management-ofsome-problem-soils/acid-soils/en/ (verified on April 24, 2016).

Gholizadeh, A., Ardalan, M., Tehrani, M.M., Hossein, H. M., Karimian, N. 2009. Solubility test in some phosphate rocks and their potential for direct application in soil. World Applied Sciences Journal. 6: 182-190.

Gómez, D.A., Carpena, R.O. 2014. Effect of 1-naphthaleneacetic acid on organic acid exudation by the roots of white lupin plants grown under phosphorus-deficient conditions. Journal of Plant Physiology. 171: 1354-1361. Gouveia, D.H., Azevedo, E.A. 1949. Caracteristicas e distribuição dos solos de Moçambique: I - Carta provisória dos solos do sul do Save; II - Esboço Pedologico da Colónia de Moçambique. Trabalhos do Centro de Investigação Cientifica Algodoeira, Moçambique. 
Goyne, K.W., Brantley, S.L., Chorover, J. 2006. Effects of organic acids and dissolved oxygen on apatite and chalcopyrite dissolution: Implications for using elements as organomarkers and oxymarkers. Chemical Geology. 234: $28-45$.

Goyne, K.W., Brantley, S.L., Chorover, J. 2010. Rare earth element release from phosphate minerals in the presence of organic acids. Chemical Geology. 278: 1-14.

Grant, W.H. 1969. Abrasion pH, an index of chemical weathering. Clays and Clay Minerals. 17: 151-155.

Harouiya, N., Chairat, C., Köhler, S.J., Gout, R., Oelkers, E.H. 2007. The dissolution kinetics and apparent solubility of natural apatite in closed reactors at temperatures from 5 to $50{ }^{\circ} \mathrm{C}$ and $\mathrm{pH}$ from 1 to 6 . Chemical Geology. 244: 554-568.

IAEA (International Atomic Energy Agency). 2002. Assessment of soil phosphorus status and management of phosphatic fertilisers to optimise crop production. IAEA, Austria.

Joergensen, R.G., Wichern, F. 2008. Quantitative assessment of the fungal contribution to microbial tissue in soil. Soil Biology and Biochemistry. 40: 2977-2991.

Khasawneh, F.E., Doll, E.C. 1978. The use of phosphate rock for direct application to soil. Advances in Agronomy. 30: 159-206.

Klugh-Stewart, K., Cumming, J.R. 2009. Organic acid exudation by mycorrhizal Andropogon virginicus L. (broomsedge) roots in response to aluminum. Soil Biology and Biochemistry. 41: 367-373.

Kpomblekou, A. K., Tabatabai, M. 2003. Effect of low-molecular weight organic acids on phosphorus release and phytoavailability of phosphorus in phosphate rocks added to soils. Agriculture, Ecosystems and Environment. 100: 275-284.

Kuo, S. 1996. Phosphorus. In Sparks, et al. (eds.), Methods of Soil Analysis Part 3 - Chemical Methods. Soil Science Society of America, American Society of Agronomy, Madison. pp. 869-919.

Langmuir, D. 1997. Aqueous environmental geochemistry. Prentice Hall, New Jersey.

Li, Y.S., Gao, Y., Tian, Q.Y., Shi, F.L., Li, L.H., Zhang, W.H. 2011. Stimulation of root acid phosphatase by phosphorus deficiency is regulated by ethylene in Medicago falcata. Environmental and Experimental Botany. 71: $114-120$.

Liu, Z., Yuan, D., Dreybrodt, W. 2005. Comparative study of dissolution rate-determining mechanisms of limestone and dolomite. Environmental Geology. 49: 274-279.

Manahan, S.E. 2000. Soil Environmental Chemistry. Environmental Chemistry. Boca Raton: CRC Press LLC, USA. 
Maria, R.M., Yost, R. 2006. A survey of soil fertility status of four agroecological zones of Mozambique. Soil Science. 171: 902-914.

Marschner, P., Crowley, D., Rengel, Z. 2011. Rhizosphere interactions between microorganisms and plants govern iron and phosphorus acquisition along the root axis - model and research methods. Soil Biology and Biochemistry. 43: 883-894.

Meloun, M., Sánka, M., Nemec, P., Kritková, S., Kupka, K. 2005. The analysis of soil cores polluted with certain metals using the Box-Cox transformation. Environmental Pollution. 137: 273-280.

Olsson, P.A., Wallander, H. 1998. Interactions between ectomycorrhizal fungi and the bacterial community in soils amended with various primary minerals. FEMS Microbiology Ecology. 27: 195-205.

Panhwar, Q.A., Naher, U.A., Radziah, O., Shamshuddin, J., Mohd Razi, I. 2014. Fertilizer, ground magnesium limestone and basalt applications may improve chemical properties of Malaysian acid sulfate soils and rice growth. Pedosphere. 24: 827-835.

Pansu, M., Gautheyrou, J. 2006. Handbook of soil analysis: Mineralogical, Organic and Inorganic Methods. Springer-Verlad, Berlin Heidelberg, New York.

Pokrovsky, O.S., Golubev, S.V., Schott, J., Castillo, A. 2009. Calcite, dolomite and magnesite dissolution kinetics in aqueous solutions at acid to circumneutral $\mathrm{pH}, 25$ to $150{ }^{\circ} \mathrm{C}$ and 1 to $55 \mathrm{~atm} \mathrm{pCO}_{2}$ : New constraints on $\mathrm{CO}_{2}$ sequestration in sedimentary basins. Chemical Geology. 265: 20-32.

Rajan, S.S.S., Brown, M.W., Boyes, M.K., Upsdell, M.P. 1992. Extractable phosphorus to predict agronomic effectiveness of ground and unground phosphate rocks. Fertilizer Research. 32: 291-302.

Robarge, W.P. 1999. Precipitation/Dissolution reactions in soils. In: Sparks, D.L. (eds). Soil physical chemistry. $2^{\text {nd }}$ Edn. CRC Press, USA. pp. 193-238.

Romero, R., Taboada, T.M., Garcia, C., Macías, F. 1987. Use of abrasion pH as an index of weathering and pedogenesis degree in granitic soils of A Coruña (Spain). Cuadernos do Laboratorio Xeológico de Laxe 11: 171182 (in Spanish).

Szilas, C. 2002. The Tanzanian Minjingu Phosphate Rocks - possibilities and limitation for direct application. PhD Dissertation, Royal Veterinary and Agricultural University, Denmark.

Szilas, C., Semoka, J. M.R., Borggaard, O.K. 2007. Can local Minjingu phosphate rock replace superphosphate on acid soils in Tanzania? Nutrient Cycling in Agroecosystems. 77: 257-268.

Szilas, C., Koch, C.B., Msolla, M.M., Borggaard, O.K. 2008. The reactivity of Tanzanian Minjingu phosphate rock can be assessed from the chemical and mineralogical composition. Geoderma. 147: 172- 177. 
Tiritan, C.S., Büll, L., Crusciol, C., Antonio, C.A., Carmeis, F. 2016. Tillage system and lime application in a tropical region: Soil chemical fertility and corn yield in succession to degraded pastures. Soil and Tillage Research. 155: 437-447.

Truong, B., Fayard, C. 1995. Small-scale fertilizer production units using raw and partially solubilized phosphate. In: H. Gerner and A.U. Mokwunye (eds). Use of phosphate rock for sustainable agriculture in West Africa. Muscle Shoals, Alabama, USA. pp. 181-198.

Turpault, M.P., Nys, C., Calvaruso, C. 2009. Rhizosphere impact on the dissolution of test minerals in a forest ecosystem. Geoderma. 153: 147-154.

Van Raij, B. 2011. Fertilidade do solo e Maneio de Nutrientes. Instituto Agronómico de Campinas, Piracicaba, Brasil.

Van Straaten, P. 2002. Rocks for crops: Agrominerals of sub-Saharan Africa. ICRAF, Nairobi, Kenya.

Van Straaten, P. 2006. Farming with rocks and minerals: challenges and opportunities. Anais da Academia Brasileira de Ciencias. 78: 731-747.

Van Straaten, P. 2007. Agrogeology: The use of rocks for crops. Enviroquest Ltd., Canada.

Viadé, A. Fernandez-Marcos, M.L., Hernández-Nistal, J., Álvarez, E. 2011. Effect of particle size of limestone on $\mathrm{Ca}, \mathrm{Mg}$ and $\mathrm{K}$ contents in soil and in sward plants. Scientia Agricola. 68: 200-208.

Wei, W., Zhang, J., Cui, J., Wei, Z. 2011. Interaction between low molecular weight organic acids and hydroxyapatite with different degrees of crystallinity. Colloids and Surfaces A: Physicochemical and Engineering Aspects. 392: 67-75.

Weindorf, D. C., Chakraborty, S. 2016. Portable X-ray fluorescence spectrometry analysis of soils. Methods of Soil Analysis. Soil Science Society of America. 1: 2-8.

Yasuda, E.Y., dos Santos, R.G., Trevisan, O.V. 2013. Kinetics of carbonate dissolution and its effects on the porosity and permeability of consolidated porous media. Journal of Petroleum Science and Engineering. 112: 284-289.

Zapata, F., Roy, R.N. 2004. Use of phosphate rocks for sustainable agriculture. FAO, Rome, Italy.

Zimdahl, R.L. 2015. Chapter 3 - Lime: A Soil Amendment. In Zimdahl, R.L. (eds.) Six Chemicals That Changed Agriculture, Academic Press, Elsevier, Netherlands. pp. 41-54. 
Table I

Elemental analysis and corresponding composition in oxides of the phosphate rock and dolostone from Mozambique used for the trials. Numbers in parentheses are the standard deviations $(n=3)$

\begin{tabular}{|c|c|c|c|c|c|c|c|}
\hline \multicolumn{4}{|c|}{ Phosphate rock } & \multicolumn{4}{|c|}{ Dolostone } \\
\hline Element & $\mathrm{mg} \mathrm{kg}^{-1}$ & Oxide & $\mathrm{mmol} \mathrm{kg}{ }^{-1}$ & Element & $\mathrm{mg} \mathrm{kg}^{-1}$ & Oxide & $\mathrm{mmol} \mathrm{kg}{ }^{-1}$ \\
\hline $\mathrm{Si}$ & $20,161(240)$ & $\mathrm{SiO}_{2}$ & $718.0(8.6)$ & $\mathrm{Si}$ & $12,942(242)$ & $\mathrm{SiO}_{2}$ & $460.9(8.6)$ \\
\hline $\mathrm{C}$ & $<\mathrm{LOD}^{\mathrm{a})}$ & $\mathrm{CO}_{3}$ & $<$ LOD & $\mathrm{C}$ & $82,122(3250)$ & $\mathrm{CO}_{3}$ & $6843(271)$ \\
\hline $\mathrm{Al}$ & $7684(485)$ & $\mathrm{Al}_{2} \mathrm{O}_{3}$ & $142.8(9.0)$ & $\mathrm{Al}$ & $2439(1241)$ & $\mathrm{Al}_{2} \mathrm{O}_{3}$ & $45.3(23.1)$ \\
\hline $\mathrm{Fe}$ & 7378 (63) & $\mathrm{Fe}_{2} \mathrm{O}_{3}$ & $66.1(0.6)$ & $\mathrm{Fe}$ & $1411(19)$ & $\mathrm{Fe}_{2} \mathrm{O}_{3}$ & $12.6(0.2)$ \\
\hline $\mathrm{P}$ & $239,666(690)$ & $\mathrm{P}_{2} \mathrm{O}_{5}$ & $3866(11)$ & $\mathrm{P}$ & $2801(160)$ & $\mathrm{P}_{2} \mathrm{O}_{5}$ & $45.2(2.6)$ \\
\hline $\mathrm{Ca}$ & $362,923(5,277)$ & $\mathrm{CaO}$ & 9073 (132) & $\mathrm{Ca}$ & $293,958(1751)$ & $\mathrm{CaO}$ & 7349 (44) \\
\hline $\mathrm{Mg}$ & $<$ LOD & $\mathrm{MgO}$ & $<$ LOD & $\mathrm{Mg}$ & $181,719(4508)$ & $\mathrm{MgO}$ & 7478 (186) \\
\hline $\mathrm{K}$ & $3275(123)$ & $\mathrm{K}_{2} \mathrm{O}$ & $42.0(1.6)$ & $\mathrm{K}$ & $695(67)$ & $\mathrm{K}_{2} \mathrm{O}$ & $8.9(0.9)$ \\
\hline $\mathrm{S}$ & $<\mathrm{LOD}$ & $\mathrm{SO}_{2}$ & $<\mathrm{LOD}$ & $\mathrm{S}$ & $315(31)$ & $\mathrm{SO}_{2}$ & $9.8(1.0)$ \\
\hline $\mathrm{Ba}$ & $2004(112)$ & $\mathrm{BaO}$ & $14.6(0.8)$ & $\mathrm{Ba}$ & $332(56)$ & $\mathrm{BaO}$ & $2.4(0.4)$ \\
\hline $\mathrm{Sr}$ & $2572(39)$ & $\mathrm{SrO}$ & $29.4(0.5)$ & $\mathrm{Sr}$ & $285(4)$ & $\mathrm{SrO}$ & $3.3(0.1)$ \\
\hline $\mathrm{Cl}$ & $1254(171)$ & $\mathrm{ClO}_{2}$ & $35.4(4.8)$ & $\mathrm{Cl}$ & $<$ LOD & $\mathrm{ClO}_{2}$ & $<$ LOD \\
\hline $\mathrm{Ti}$ & $1228(22)$ & $\mathrm{TiO}_{2}$ & $25.7(0.5)$ & $\mathrm{Ti}$ & $114(8)$ & $\mathrm{TiO}_{2}$ & $2.4(0.2)$ \\
\hline $\mathrm{Mn}$ & $498(11)$ & $\mathrm{MnO}_{2}$ & $9.1(0.2)$ & $\mathrm{Mn}$ & $448(8)$ & $\mathrm{MnO}_{2}$ & $8.2(0.2)$ \\
\hline
\end{tabular}




\section{Table II}

Abrasion $\mathrm{pH}$ at different contact times of different particle size fractions of phosphate rock and dolostone from Mozambique. Numbers in parentheses are the standard deviations $(n=3)$.

\begin{tabular}{|c|c|c|c|c|c|c|}
\hline \multirow{2}{*}{$\begin{array}{l}\text { Contact time } \\
\text { (hours) }\end{array}$} & \multicolumn{3}{|c|}{ Particle size } & \multicolumn{3}{|c|}{$\mathrm{ANOVA}^{\mathrm{a})}$} \\
\hline & $0.063-0.25 \mathrm{~mm}$ & $0.25-0.5 \mathrm{~mm}$ & $0.5-2 \mathrm{~mm}$ & Contact time & Rock size & $\begin{array}{l}\text { Contact time } \mathrm{x} \\
\text { Rock size }\end{array}$ \\
\hline \multicolumn{7}{|c|}{ Phosphate rock } \\
\hline 0.1 & $9.36(0.01) \mathrm{aA}^{\mathrm{b})}$ & $8.63(0.23) \mathrm{bA}$ & $8.66(0.02) \mathrm{bA}$ & \multirow{3}{*}{$* * *$} & \multirow{3}{*}{$* * *$} & \multirow{3}{*}{$* *$} \\
\hline 1.5 & 8.24 (0.07) aB & $7.79(0.01) \mathrm{bB}$ & $7.69(0.01) \mathrm{bB}$ & & & \\
\hline 24 & $8.23(0.08) \mathrm{aB}$ & $7.98(0.03) \mathrm{bB}$ & $7.81(0.03) \mathrm{bB}$ & & & \\
\hline \multicolumn{7}{|l|}{ Dolostone } \\
\hline 0.1 & $9.36(0.04) \mathrm{aA}$ & $9.57(0.14) \mathrm{aA}$ & $9.50(0.11) \mathrm{aA}$ & \multirow{3}{*}{$* * *$} & \multirow{3}{*}{$*$} & \multirow{3}{*}{$* *$} \\
\hline 1.5 & $8.73(0.10) \mathrm{aB}$ & $8.81(0.05) \mathrm{aB}$ & $8.66(0.03) \mathrm{aB}$ & & & \\
\hline 24 & $8.29(0.03) \mathrm{aC}$ & $8.27(0.03) \mathrm{aC}$ & $8.25(0.03) \mathrm{aC}$ & & & \\
\hline
\end{tabular}

a) * Significant at the 0.05 probability level; ** Significant at the 0.01 probability level; *** Significant at the 0.001 probability level.

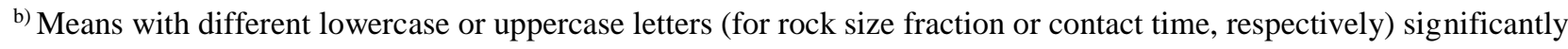
differed per Tukey multiple mean comparison test at the $95 \%$ level of significance.

\section{Table III}

Reactivity of the different particle-size fractions of phosphate rock from Mozambique in water, neutral ammonium citrate (NAC), $2 \%$ citric acid solution and 2\% formic acid solution. Numbers in parentheses are the standard deviation $(n=3)$. The values are express as the percentage of $\mathrm{P}_{2} \mathrm{O}_{5}$ extracted from the rock fractions

\begin{tabular}{cccccc}
\hline & \multicolumn{5}{c}{ Extractant } \\
\cline { 2 - 5 } Particle size & Water & NAC & $2 \%$ citric acid & 2\% formic acid & ANOVA a) $^{*}$ \\
\hline $0.063-0.25 \mathrm{~mm}$ & $0.14(0.01) \mathrm{d} \mathrm{A}^{\mathrm{b})}$ & $1.90(0.42) \mathrm{c} \mathrm{A}$ & $8.74(0.04) \mathrm{b} \mathrm{A}$ & $13.34(1.33) \mathrm{a} \mathrm{A}$ & \\
$0.25-0.5 \mathrm{~mm}$ & $0.11(0.01) \mathrm{d} \mathrm{A}$ & $0.63(0.13) \mathrm{c} \mathrm{B}$ & $5.34(0.26) \mathrm{b} \mathrm{B}$ & $7.19(0.26) \mathrm{a} \mathrm{B}$ & $* * *$ \\
$0.5-2 \mathrm{~mm}$ & $0.08(0.00) \mathrm{c} \mathrm{A}$ & $0.37(0.25) \mathrm{b} \mathrm{B}$ & $4.35(0.37) \mathrm{a} \mathrm{B}$ & $5.42(0.63) \mathrm{a} \mathrm{C}$ & \\
\hline
\end{tabular}

a) $* * *$ Significant at the 0.001 probability level.

b) Means with different lowercase and uppercase letters (for extractants or particle size fraction, respectively) significantly differ per Tukey multiple mean comparison test at $95 \%$ of significance. 


\section{Table IV}

Cumulative amounts of $\mathrm{P}, \mathrm{Ca}$ and $\mathrm{Mg}\left(\mathrm{mmol} \mathrm{kg}^{-1}\right)$ released in water, citric acid solution at $\mathrm{pH} 4$ and citric acid solution at $\mathrm{pH} 2$ during the extraction time between 24 and $360 \mathrm{~h}$ by the different particle-size fractions of phosphate rock from Mozambique. Numbers in parentheses are the standard deviation $(\mathrm{n}=3)$.

\begin{tabular}{|c|c|c|c|c|c|c|c|}
\hline \multirow[b]{2}{*}{ Element } & \multirow[b]{2}{*}{ Leaching solution } & \multicolumn{3}{|c|}{ Particle size } & \multicolumn{3}{|c|}{ ANOVA $^{\text {a) }}$} \\
\hline & & $0.063-0.25 \mathrm{~mm}$ & $0.25-0.5 \mathrm{~mm}$ & $0.5-2 \mathrm{~mm}$ & $\begin{array}{l}\text { Rock size } \\
\text { fraction }\end{array}$ & $\begin{array}{l}\text { Leaching } \\
\text { solution }\end{array}$ & $\begin{array}{l}\text { Rock size fraction } x \\
\text { Leaching solution }\end{array}$ \\
\hline \multirow[t]{3}{*}{$\mathrm{P}$} & Water & $11.8(3.1) \mathrm{aA}^{\mathrm{b})}$ & $6.7(0.5) \mathrm{bA}$ & $7.7(0.6) \mathrm{bA}$ & & & \\
\hline & Citric acid at $\mathrm{pH} 4$ & $67.6(2.3) \mathrm{aB}$ & $49.3(5.9) \mathrm{bB}$ & 61.6 (4.9) aB & $* * *$ & $* * *$ & $* *$ \\
\hline & Citric acid at $\mathrm{pH} 2$ & $1874.7(23.8) \mathrm{aC}$ & $1826(35) \mathrm{aC}$ & 1702 (118) aC & & & \\
\hline \multirow[t]{3}{*}{$\mathrm{Ca}$} & Water & $4.9(1.6) \mathrm{aA}$ & $2(0.6) \mathrm{bA}$ & $1.1(0.1) \mathrm{bA}$ & & & \\
\hline & Citric acid at $\mathrm{pH} 4$ & $16.3(0.8) \mathrm{aB}$ & $4.8(0.3) \mathrm{bB}$ & $8.2(0.8) \mathrm{cB}$ & $* * *$ & $* * *$ & $* *$ \\
\hline & Citric acid at $\mathrm{pH} 2$ & $1367(95) \mathrm{aC}$ & $1244(124) \mathrm{aC}$ & $1308(212) \mathrm{aC}$ & & & \\
\hline \multirow[t]{3}{*}{$\mathrm{Mg}$} & Water & $1.7(0.7) \mathrm{aA}$ & $0.9(0.43) \mathrm{bA}$ & $0.6(0.1) \mathrm{bA}$ & & & \\
\hline & Citric acid at $\mathrm{pH} 4$ & $0.8(0.2) \mathrm{aB}$ & $0.6(0.2) \mathrm{aA}$ & $1.2(0.0) \mathrm{aB}$ & $* * *$ & $* * *$ & $* *$ \\
\hline & Citric acid at $\mathrm{pH} 2$ & $14.2(1.3) \mathrm{aC}$ & $27.4(2.4) \mathrm{bB}$ & $25.0(5.4) \mathrm{bC}$ & & & \\
\hline
\end{tabular}

a) ** Significant at the 0.01 probability level; *** Significant at the 0.001 probability level.

b) Means with different lowercase or uppercase letters (for rock size fraction or leaching solution, respectively) significantly differed per Tukey multiple mean comparison test at $95 \%$ of significance. 
Table V

Amounts of $\mathrm{P}$ and $\mathrm{Ca}\left(\mathrm{mmol} \mathrm{kg}^{-1}\right)$ released in water and $2 \%$ citric acid solution during the leaching and single extraction by the different size fractions of phosphate rock from Mozambique. Numbers in parentheses are the standard deviation $(\mathrm{n}=3)$

\begin{tabular}{|c|c|c|c|c|c|c|}
\hline \multirow[b]{2}{*}{ Element } & \multirow[b]{2}{*}{ Extractant } & \multirow{2}{*}{$\begin{array}{l}\text { Type of } \\
\text { extraction }\end{array}$} & \multicolumn{3}{|c|}{ Particle size } & \multirow[b]{2}{*}{ ANOVA $^{a)}$} \\
\hline & & & $0.063-0.25 \mathrm{~mm}$ & $0.25-0.5 \mathrm{~mm}$ & $0.5-2 \mathrm{~mm}$ & \\
\hline \multirow[t]{4}{*}{$\mathrm{P}$} & Water & Single & $19.7(1.5) \mathrm{a} \mathrm{A}^{\mathrm{b})}$ & $15.0(1.7) \mathrm{b} \mathrm{A}$ & $11.0(0.0) \mathrm{c} \mathrm{A}$ & \multirow{4}{*}{$* *$} \\
\hline & \multirow{3}{*}{$2 \%$ Citric acid } & Leaching & 62.7 (4.6) a B & 35.3 (3.2) b B & 30.7 (2.1) b B & \\
\hline & & Single & 1231 (5) a A & 751.7 (36.1) b A & 613.0 (52.0) b B & \\
\hline & & Leaching & 5375 (135) a B & 4590 (197) a B & 3492 (296) b B & \\
\hline \multirow[t]{4}{*}{$\mathrm{Ca}$} & Water & Single & $1.0(0.0)$ a A & $1.0(0.0)$ a $\mathrm{A}$ & $1.0(0.0)$ a A & \multirow{4}{*}{$* *$} \\
\hline & \multirow{3}{*}{$2 \%$ Citric acid } & Leaching & 16.7 (2.5) a B & $9.0(0.0) \mathrm{b}$ B & 7.7 (1.5) b B & \\
\hline & & Single & 485.3 (18.5) a A & 219.3 (17.4) b A & 165.7 (4.6) b A & \\
\hline & & Leaching & 4328 (263) a B & 3094 (192) b B & 2285 (320) b B & \\
\hline \multirow[t]{4}{*}{ Ca:P } & Water & Single & $0.05(0.03)$ a $\mathrm{A}$ & $0.07(0.01)$ a $\mathrm{A}$ & $0.09(0.01)$ a $\mathrm{A}$ & \multirow{4}{*}{$* *$} \\
\hline & \multirow{3}{*}{$2 \%$ Citric acid } & Leaching & $0.27(0.06)$ a B & $0.25(0.02)$ a B & $0.25(0.03)$ a B & \\
\hline & & Single & $0.39(0.02)$ a $\mathrm{A}$ & $0.29(0.01)$ a $\mathrm{A}$ & $0.26(0.02)$ a $\mathrm{A}$ & \\
\hline & & Leaching & $0.81(0.05)$ a B & $0.67(0.02)$ a B & $0.65(0.05)$ a B & \\
\hline
\end{tabular}

a) ** Significant at the 0.01 probability level

b) Means with different lowercase and uppercase letters (for particle size fraction or type of extraction, respectively) significantly differed per Tukey multiple mean comparison test at $95 \%$ of significance. 


\section{Table VI}

Cumulative amounts of $\mathrm{Ca}, \mathrm{Mg}$ and $\mathrm{K}\left(\mathrm{mmol} \mathrm{kg}^{-1}\right)$ released in water, citric acid solution at $\mathrm{pH} 4$ and citric acid solution at $\mathrm{pH} 2$ during the extraction time between 24 and $360 \mathrm{~h}$ by the different particle-size fractions of dolostone from Mozambique. Numbers in parentheses are the standard deviation $(n=3)$

\begin{tabular}{|c|c|c|c|c|c|}
\hline \multirow[b]{2}{*}{ Element } & \multirow[b]{2}{*}{ Leaching solution } & \multicolumn{3}{|c|}{ Particle size } & \multirow[b]{2}{*}{ ANOVA $^{\text {a) }}$} \\
\hline & & $0.063-0.25 \mathrm{~mm}$ & $0.25-0.5 \mathrm{~mm}$ & $0.5-2 \mathrm{~mm}$ & \\
\hline \multirow[t]{3}{*}{$\mathrm{Ca}$} & Water & $57.7(0.7) \mathrm{a} \mathrm{A}^{\mathrm{b})}$ & 37.9 (4.3) b A & $26.9(1.6)$ c A & \multirow{3}{*}{$* *$} \\
\hline & Citric acid at $\mathrm{pH} 4$ & $73.2(16.0)$ a $\mathrm{A}$ & $55.8(1.2) \mathrm{a} \mathrm{A}$ & 56.3 (4.6) a B & \\
\hline & Citric acid at $\mathrm{pH} 2$ & $643.0(413.1)$ a B & 1747 (293) b C & 1600 (64) b C & \\
\hline \multirow[t]{3}{*}{$\mathrm{Mg}$} & Water & $26.5(0.4)$ a A & $23.6(3.6)$ a A & 13.7 (2.6) b A & \multirow{3}{*}{$* *$} \\
\hline & Citric acid at $\mathrm{pH} 4$ & $37.1(9.0)$ a B & $30.8(2.2)$ a A & 27.4 (1.7) a B & \\
\hline & Citric acid at $\mathrm{pH} 2$ & 579.9 (327.0) a C & 1913 (261) b B & 1782 (59) b C & \\
\hline \multirow[t]{3}{*}{ K } & Water & $0.6(0.1)$ a $\mathrm{A}$ & $0.7(0.3)$ a $\mathrm{A}$ & $0.4(0.2) \mathrm{b} \mathrm{A}$ & \multirow{3}{*}{$* *$} \\
\hline & Citric acid at $\mathrm{pH} 4$ & $0.0(0.0)$ a B & $0.1(0.0)$ a B & $0.5(0.1) \mathrm{b} \mathrm{A}$ & \\
\hline & Citric acid at $\mathrm{pH} 2$ & $0.8(0.1)$ a C & $4.9(0.5) b \mathrm{C}$ & $3.6(0.5) \mathrm{b} \mathrm{B}$ & \\
\hline
\end{tabular}

a) ** Significant at the 0.01 probability level.

b) Means with different lowercase and uppercase letters (for rock size fraction or contact time, respectively) significantly differed per Tukey multiple mean comparison test at $95 \%$ of significance. 


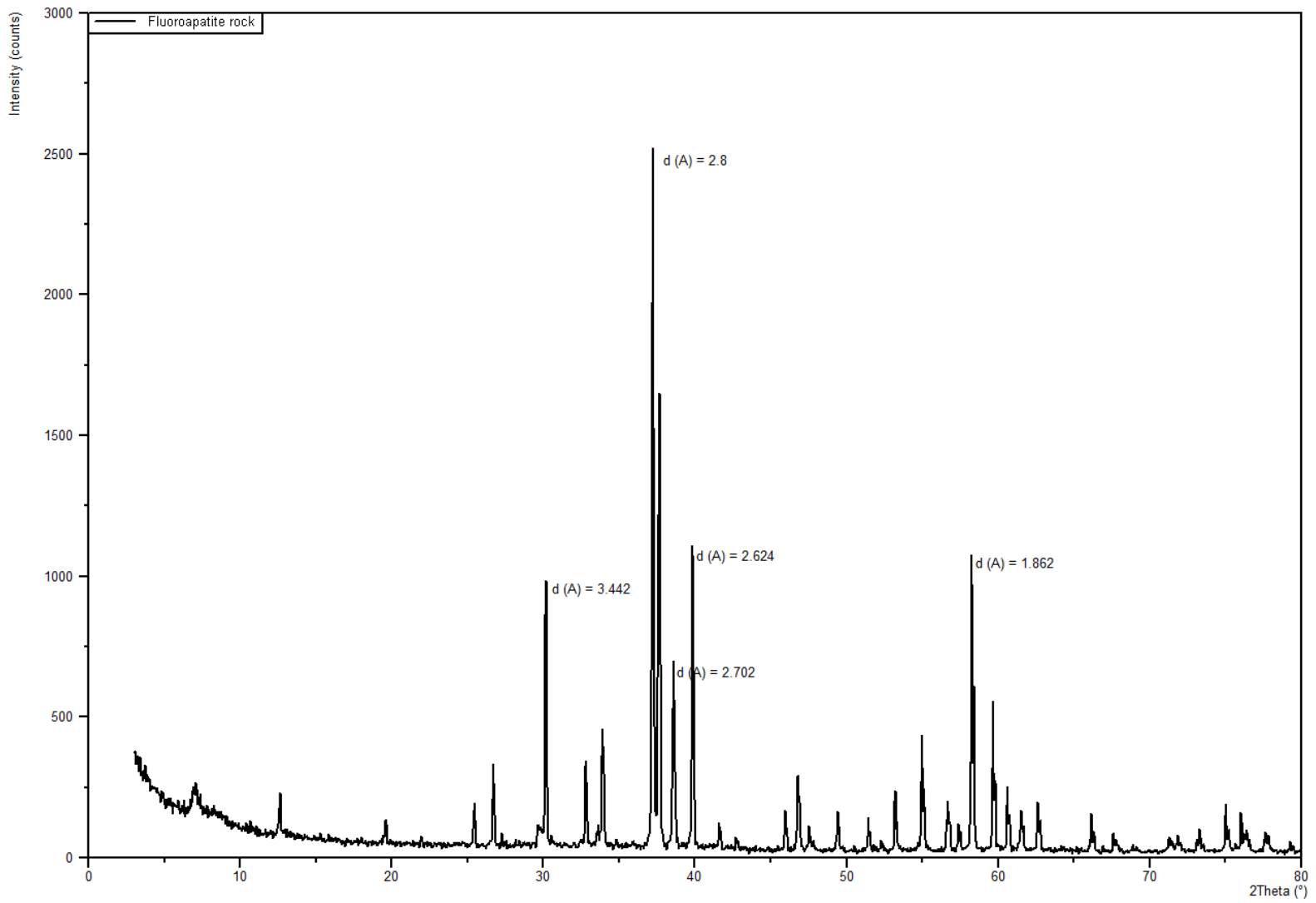

Fig. 1 X-Ray diffractogram of the phosphate rock from Mozambique, indicating a composition mostly made of fluoroapatite with traces of phyllosilicates. Beam: Co Ka1 radiation. 


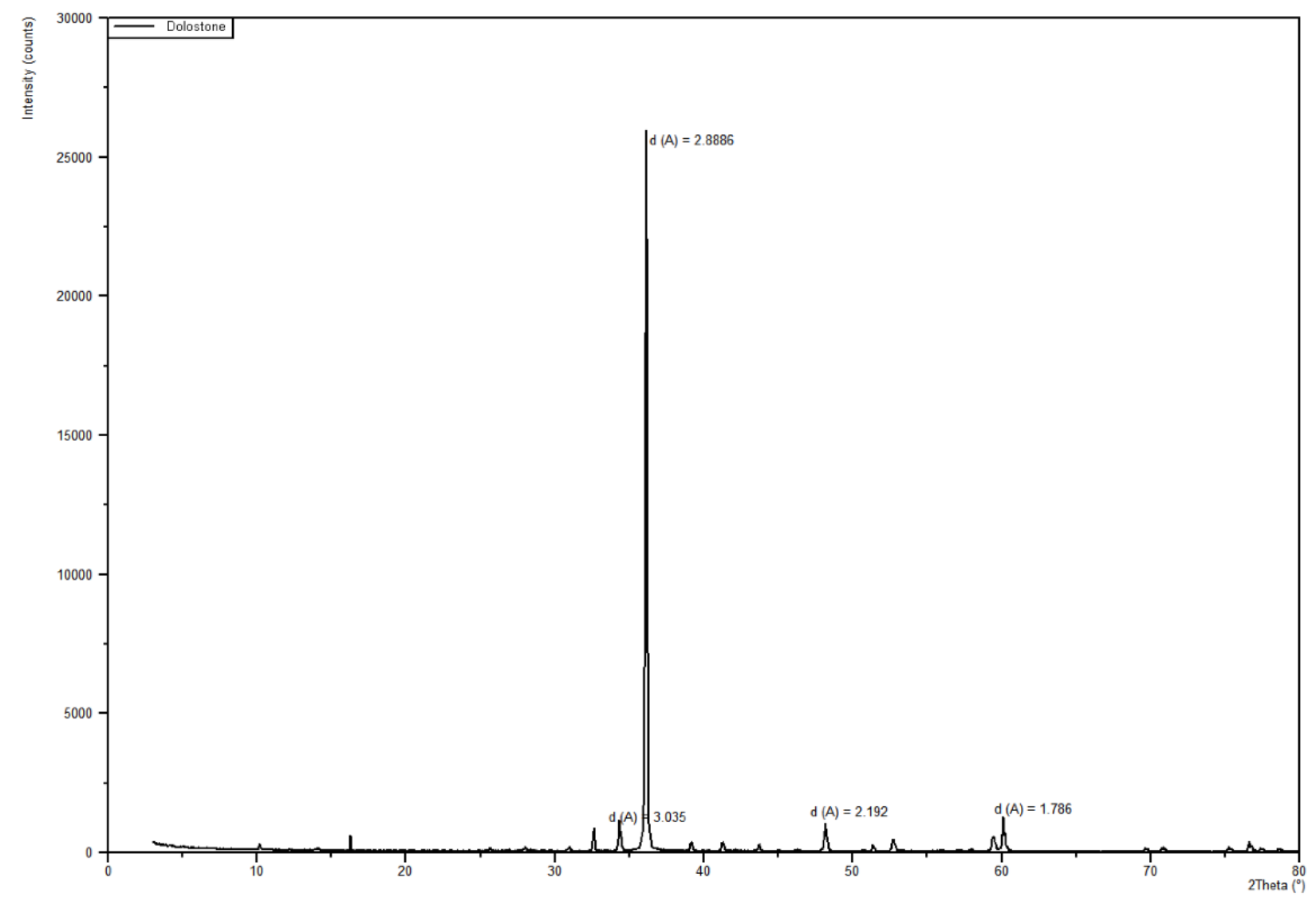

Fig. 2 X-Ray diffractogram of dolostone from Mozambique, indicating a composition mostly made of dolomite with traces of phyllosilicates. Beam: Co K $\alpha 1$ radiation. 

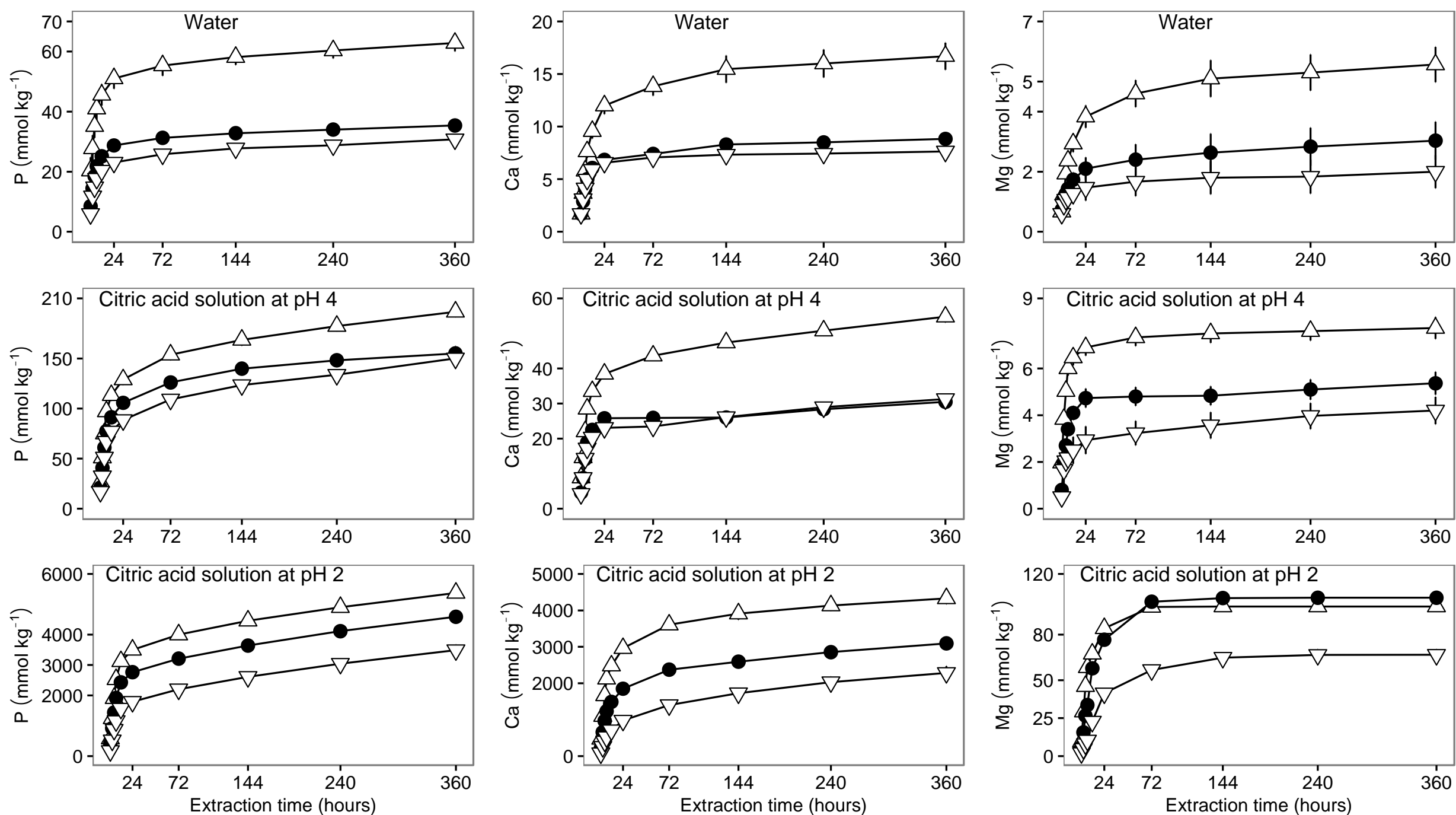

$\triangle 0.063-0.25 \mathrm{~mm} \bullet 0.25-0.5 \mathrm{~mm} \nabla 0.5-2 \mathrm{~mm}$

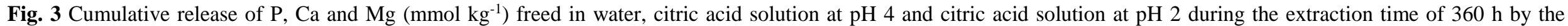
different particle-size fractions of phosphate rock from Mozambique. The whiskers indicate the error bars and represent the $95 \%$ confidence interval from triplicate leachate samples. 

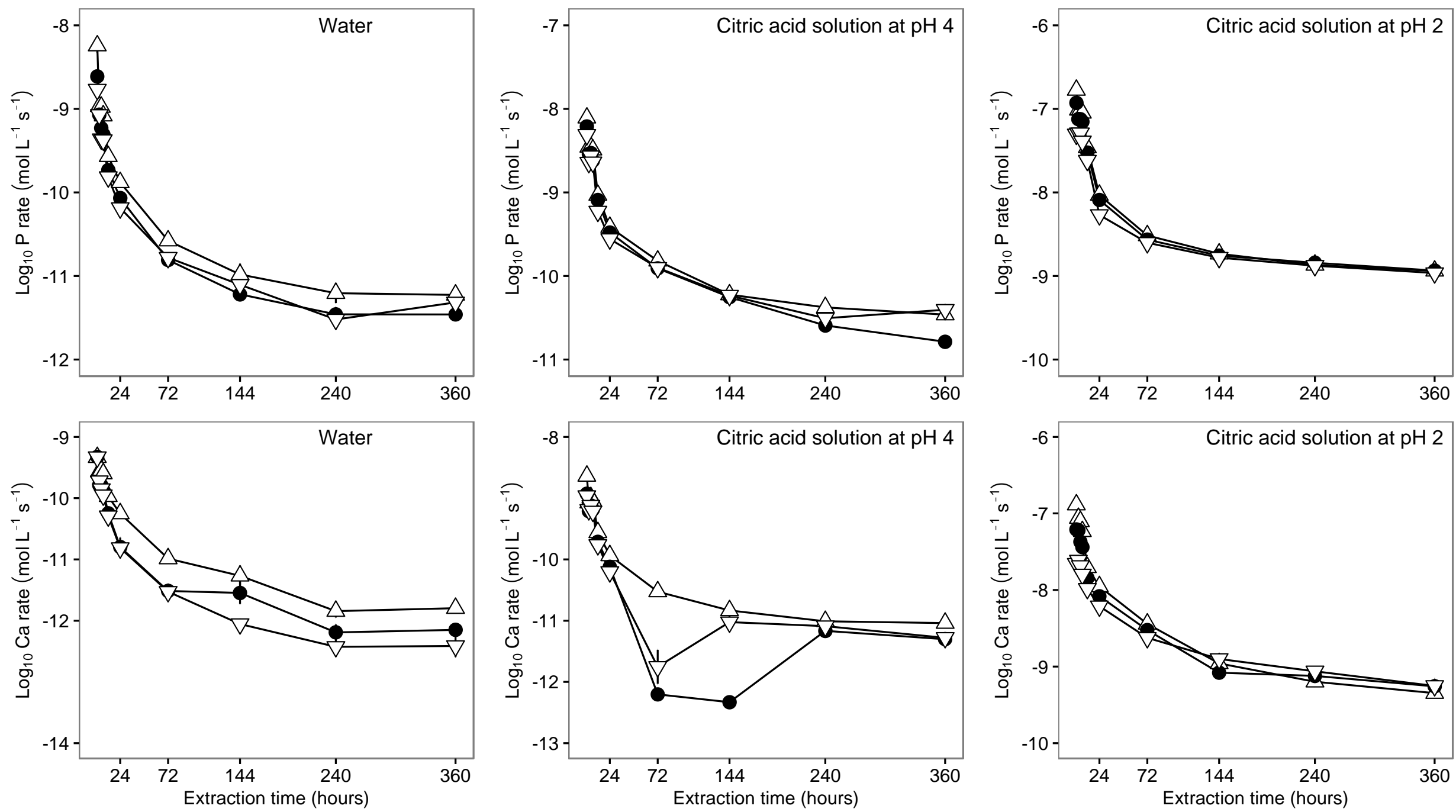

\section{$\triangle 0.063-0.25 \mathrm{~mm} \bullet 0.25-0.5 \mathrm{~mm} \nabla 0.5-2 \mathrm{~mm}$}

Fig. 4 Logarithms of releasing rate (R) of $\mathrm{P}$ and $\mathrm{Ca}\left(\mathrm{mol} \mathrm{L}^{-1} \mathrm{~s}^{-1}\right)$ for water, citric acid solution at $\mathrm{pH} 4$ and citric acid solution at $\mathrm{pH} 2$ during the extraction time of $360 \mathrm{~h}$ by the different particle-size fractions of phosphate rock from Mozambique. The whiskers indicate the error bars and represent the $95 \%$ confidence interval from triplicate leachate samples. 

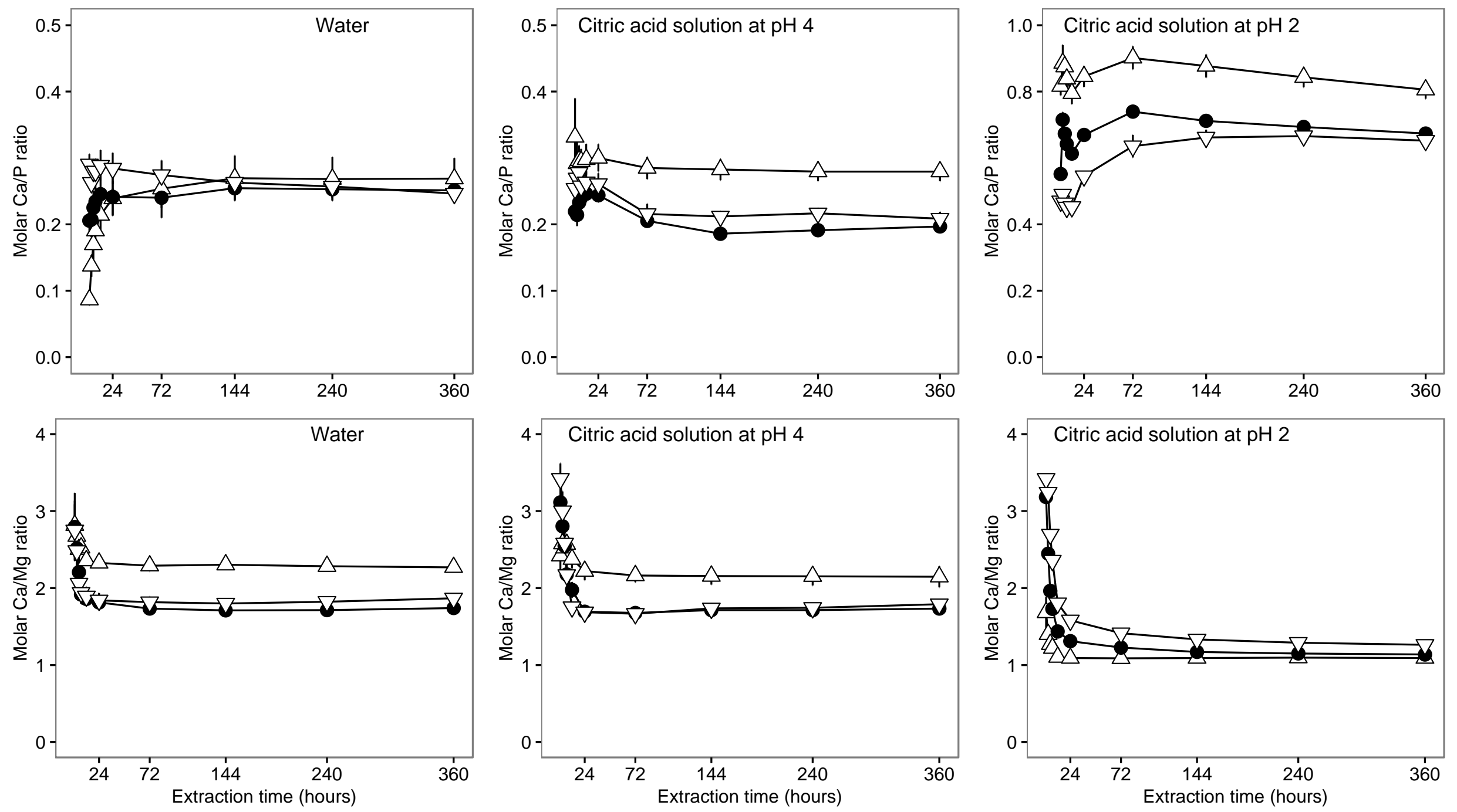

$\triangle 0.063-0.25 \mathrm{~mm} \bullet 0.25-0.5 \mathrm{~mm} \nabla 0.5-2 \mathrm{~mm}$

Fig. 5 Molar Ca:P and Ca:Mg ratios for water, citric acid solution at pH 4 and citric acid solution at $\mathrm{pH} 2$ during the extraction time of $360 \mathrm{~h}$ for the different particle-size fractions of phosphate rock and dolostone from Mozambique. The whiskers indicate the error bars and represent the 95\% confidence interval from triplicate leachate samples. 

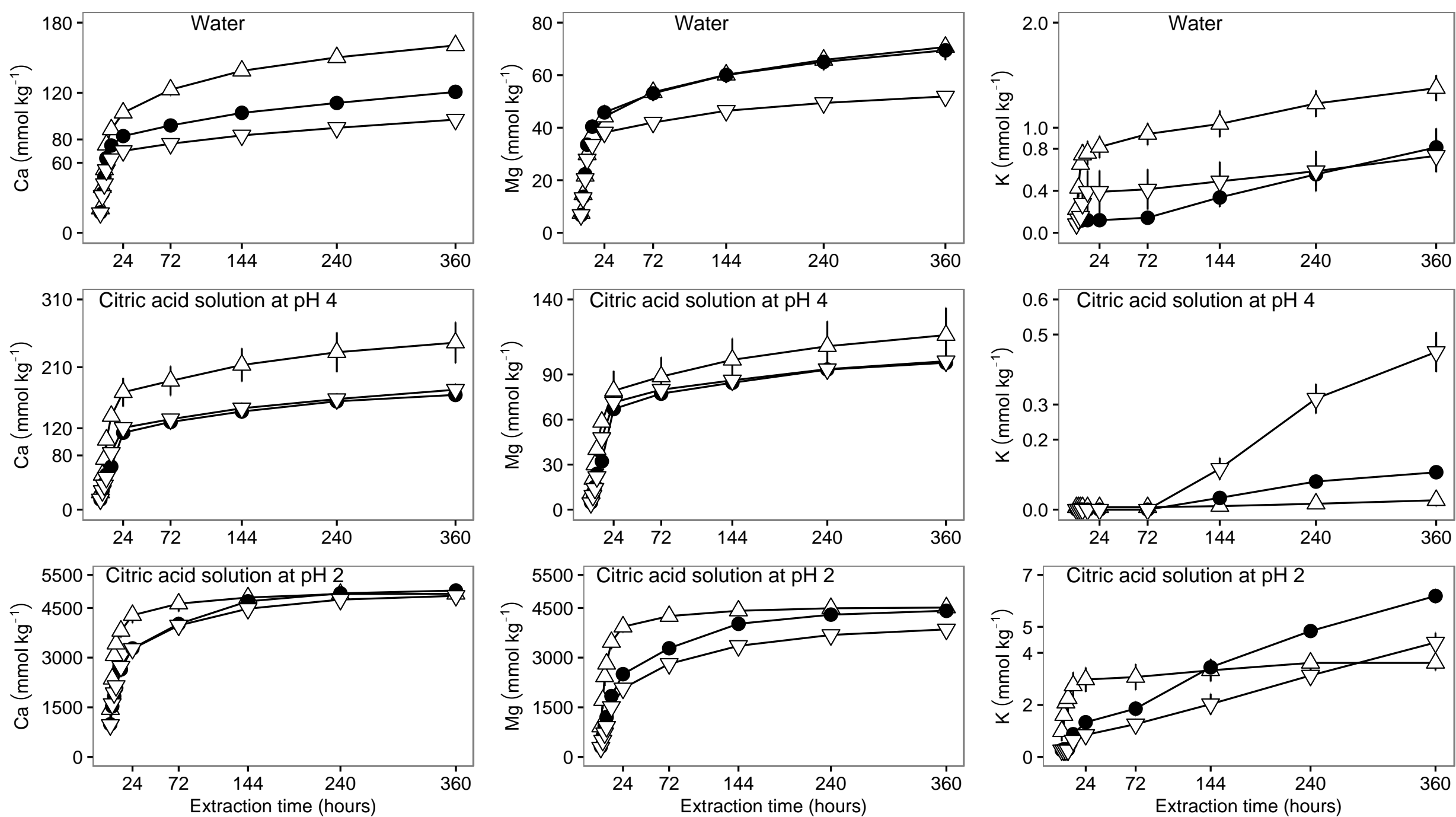

$\triangle 0.063-0.25 \mathrm{~mm} \bullet 0.25-0.5 \mathrm{~mm} \nabla 0.5-2 \mathrm{~mm}$

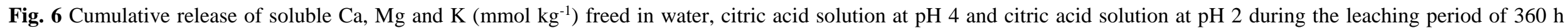

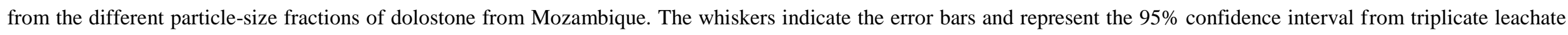
samples. 

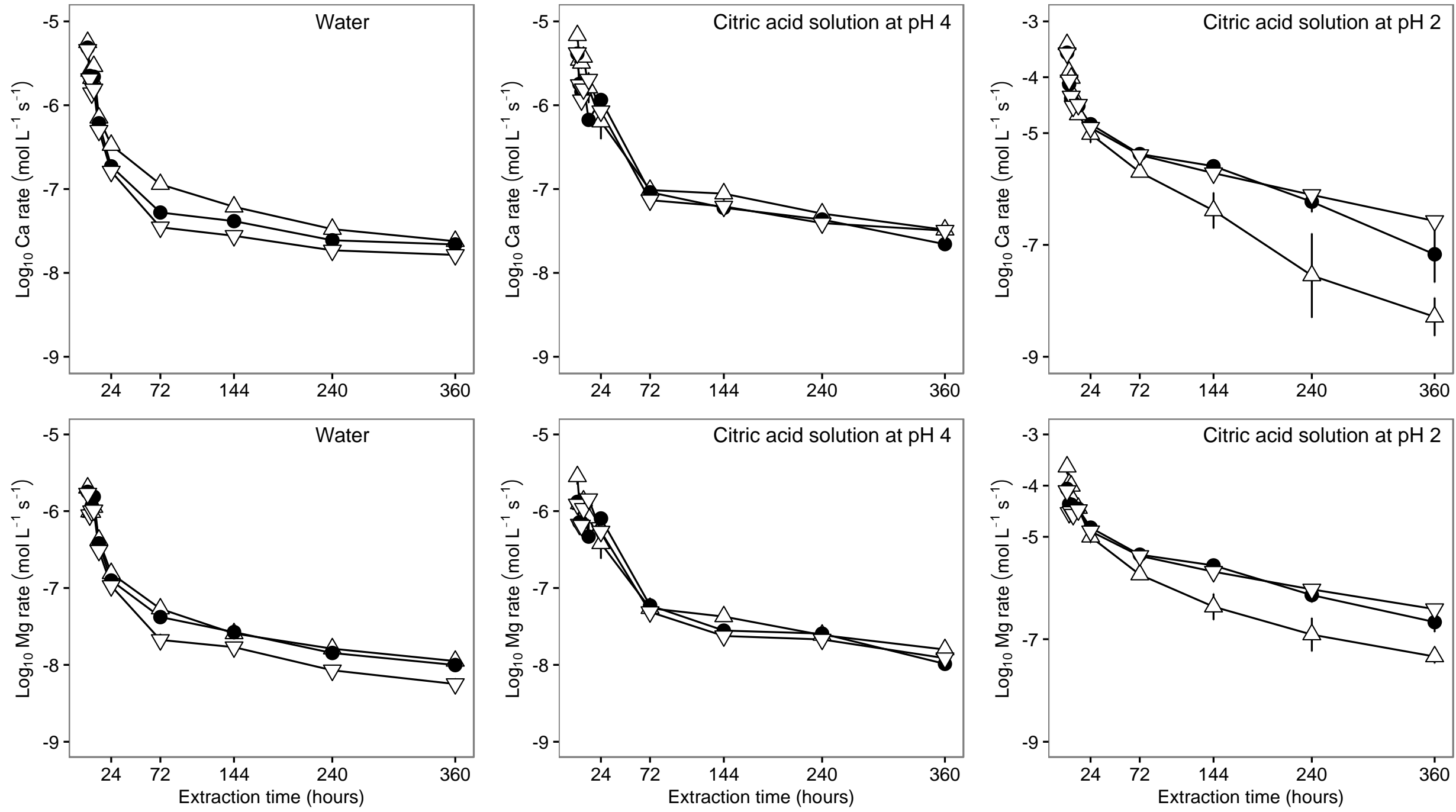

$\triangle 0.063-0.25 \mathrm{~mm} \bullet 0.25-0.5 \mathrm{~mm} \nabla 0.5-2 \mathrm{~mm}$

Fig. 7 Logarithms of releasing rate $(\mathrm{R})$ of $\mathrm{Ca}$ and $\mathrm{Mg}\left(\mathrm{mol} \mathrm{L}^{-1} \mathrm{~s}^{-1}\right)$ for water, citric acid solution at $\mathrm{pH} 4$ and citric acid solution at $\mathrm{pH} 2$ during the extraction time of $360 \mathrm{~h}$ for the different particle-size fractions of dolostone from Mozambique. The whiskers indicate the error bars and represent the $95 \%$ confidence interval from triplicate leachate samples. 